\title{
PENGEMBANGAN MULTIMEDIA INTERAKTIF SEBAGAI ALAT BANTU PEMBELAJARAN DENGAN MODEL PBL UNTUK PENINGKATAN HASIL BELAJAR MATEMATIKA
}

\author{
Novia Margarita ${ }^{1}$, Nyoto Harjono ${ }^{2}$, Gamaliel Septian Airlanda ${ }^{3}$ \\ 1,2,3 Jurusan Pendidikan Guru Sekolah Dasar, FKIP \\ Universitas Kristen Satya Wacana \\ Jawa Tengah, Indonesia \\ email : noviamargarita6@gmail.com ${ }^{1}$, har.john59@gmail.com², \\ gama.airlanda@staff.uksw.edu ${ }^{3}$
}

\begin{abstract}
Abstrak
Penelitian ini bertujuan untuk mengembangkan multimedia interaktif sebagai alat bantu untuk peningkatan hasil belajar matematika materi pecahan kelas 4 Sekolah Dasar (SD). Metode penelitian dengan Research and Development $(\mathrm{RnD})$ dengan model pengembangan ASSURE dengan 6 tahapan: 1) analyze learners characteristic , 2) state objectives, 3) select modify or design method, media or materials, 4) utilize media and materials, 5) require learners participation, 6) evaluate and revise. Kevalidan materi dan produk multimedia interaktif diuji dengan uji pakar menggunakan instrumen lembar validasi. Validasi pakar materi dengan skor persentase $86 \%$ dengan kriteria yang menunjukkan kategori sangat tinggi. Validasi media dengan skor persentase $88 \%$ dengan kategori sangat baik. Kepraktisan produk multimedia interaktif diuji dengan uji coba terbatas, 2 SD tidak menggunakan media dan 2 SD menggunakan media dengan model PBL pada saat proses pembelajaran. Hasil uji coba terbatas hasil yang ditunjukkan pada 2 SD yang tidak menggunakan media dihasilkan rata-rata nilai pretest 72,56 dan posttest 80,12 serta sig.(2-tailed) 0,004. Selanjutnya pada 2 SD yang menggunakan media dihasilkan rata-rata pretest 75,74 dan posttest 83,62 dan sig.(2-tailed) 0,000 . Berdasarkan hal tersebut multimedia interaktif yang dikembangkan valid dan materi yang terdapat dalam multimedia interaktif dapat membawa peserta didik untuk belajar secara tidak langsung dan dapat belajar secara mandiri.
\end{abstract}

Kata Kunci : Research and Development (RnD), Multimedia Interaktif, Model PBL, Matematika

\begin{abstract}
This study aims to develop interactive multimedia as a tool for improving the results of learning mathematics of grade 4 elementary school (SD). Research method with Research and Development $(R n D)$ with ASSURE development model with 6 stages: 1) analyze learners characteristic, 2) state objectives, 3) select modify or design method, media or materials, 4) utilize media and materials, 5) learners participation, 6) evaluate and revise. The validity and interactive multimedia materials and products are tested by expert tests using the validation sheet instrument. Validate material experts with an $86 \%$ percent score with criteria indicating very high category. Media validation with $88 \%$ percentage score with very good category. The practicality of interactive multimedia products was tested with limited trials, 2 SDs did not use media and 2 SDs using media with PBL models during the learning process. The results of the limited trial results shown on 2 SDs that did not use media resulted in average pretest values of 72.56 and posttest 80.12 and sig. (2-tailed) 0.004 . Furthermore, in the 2 SDs using media, the average pretest 75.74 and posttest 83.62 and sig. (2-tailed) 0.000 were generated. Based on the interactive multimedia developed and valid material contained in interactive multimedia can bring learners to learn indirectly and can learn independently.
\end{abstract}

Keywords: Research and Development (RnD), Interactive Multimedia, PBL Model, Mathematics 


\section{Pendahuluan}

Pendidikan abad 21 dalam segi kehidupan ditandai dengan perkembangan dan kemajuan teknologi, informasi dan komunikasi. Kemajuan teknologi berpengaruh dalam proses pembelajaran di sekolah ataupun lembaga pendidikan lainnya. Proses pembelajaran disekolah mulai disesuaikan dengan teknologi informasi yang dikembangkan dan diimplementasikan secara kontekstual sesuai kebutuhan daerah, peserta didik dan satuan pendidikan. Setiap daerah membutuhkan proses pembelajaran yang memungkinkan dengan kondisi, karakter dan potensi yang dimiliki peserta didik. Proses pembelajaran saat ini banyak menggunakan media pembelajaran berbantuan komputer atau laptop, satu di antaranya adalah pembelajaran matematika. Penguasaan matematika sejak dini diperlukan untuk menguasai serta menciptakan teknologi yang kuat dimasa depan (BSNP, 2006).

Penggunaan media dalam proses pembelajaran matematika yang efektif dan efisien diharapkan mampu membentuk stimulus-stimulus yang direspon melalui pola pikir peserta didik dalam menunjang tercapainya tujuan pembelajaran. Pemanfaatan media pembelajaran memerlukan adanya teknologi, informasi dan komunikasi. Media pembelajaran merupakan segala sesuatu untuk menyampaikan informasi atau pesan yang dapat merangsang perhatian dan minat peserta didik dalam setiap proses pembelajaran (Arsyad, 2016: 10).

Standar kualifikasi akademik dan kompetensi guru khususnya pada aspek kompetensi pedagogik, menjelaskan bahwa guru harus memiliki kemampuan dalam memanfaatkan teknologi informasi dan komunikasi untuk kepentingan penyelenggaraan kegiatan pengembangan yang mendidik (Permendiknas No 16 Tahun 2007).

Pembelajaran matematika sebagai ilmu universal, memiliki peran penting mendasari perkembangan teknologi modern dalam memajukan pola pikir manusia. Matematika adalah pelajaran yang dibutuhkan oleh peserta didik dalam kehidupan sehari-hari (Permendikbud Nomor 81 A). Pembelajaran matematika di Sekolah Dasar (SD) merupakan sarana berpikir ilmu dasar yang harus dimiliki peserta didik dalam menyelesaikan masalah yang berkaitan dengan kehidupan sehari-hari. Pendidikan dimasa sekarang yaitu memberi bekal peserta didik untuk belajar secara efektif dalam zaman teknologi. Pembelajaran di SD diharapkan dapat memberikan pembelajaran yang efektif dan efisien sesuai kurikulum dan pola pikir peserta didik untuk menyelesaikan masalah matematika berkaitan dengan kehidupan sehari-hari (Wahyudi dan Kriswandani, 2013).

Pembelajaran matematika di SD melibatkan 2 pihak yaitu guru sebagai fasilitator dan peserta didik sebagai pembelajar. Peserta didik masih menganggap bahwa mata pelajaran matematika sulit dan kurang menarik. Matematika dianggap sebagai mata pelajaran yang sulit sehingga kurang diminati (Giarti, 2014: 13-27). Dalam pembelajaran matematika agar menarik minat peserta didik guru dituntut untuk dapat melakukan berbagai upaya pembelajaran yang menyenangkan. Salah satunya dengan menggunakan metode pembelajaran yang dapat membuat peserta didik aktif dan menyenangkan. Selain metode, guru dapat menggunakan media pembelajaran untuk menciptakan minat peserta didik agar lebih kreatif, aktif dan inovatif dengan menggunakan media sebagai perantara dalam belajar.

Berdasarkan hasil observasi dan wawancara dengan salah satu guru di kelas 4 SD Negeri 01 Anggrasmanis, yang menggunakan kurikulum KTSP, ditemukan permasalahan yang berhubungan dengan pembelajaran matematika. Guru belum menggunakan metode dan model pembelajaran yang inovatif dan kurang memanfaatkan penggunaan media sehingga peserta didik kurang termotivasi dalam pembelajaran. Minimnya kebutuhan media pembelajaran tidak hanya di SD N 01 Anggrasmanis saja, tetapi juga dialami oleh sekolah lain seperti SD N 01 Menjing, SD N 01 Balong dan SD N 01 Kadipiro. Penggunaan media pembelajaran yang menarik dan inovatif sangat terbatas. Selain itu aktivitas yang dilakukan peserta didik kurang, terlihat selama mengikuti pembelajaran pada saat guru memberikan pertanyaan ataupun saat menjelaskan materi siswa belum aktif dan cenderung pasif. Fenomena tersebut menunjukkan bahwa proses pembelajaran di SD N 01 Anggrasmanis yang diselenggarakan selama ini belum dilakukan secara efektif dan efisien. Hal tersebut berdampak pada hasil belajar matematika 
siswa rendah dari 25 siswa terdapat 7 siswa yang lulus KKM dengan persentase $28 \%$. Ada 18 siswa yang belum lulus KKM dengan persentase $72 \%$.

Berkaitan dengan kondisi ideal dan kenyataan yang telah dijabarkan, maka terjadi kesenjangan yaitu kurangnya pemanfaatan teknologi informasi dan hasil belajar siswa yang rendah. Oleh karena itu untuk menutup kesenjangan dan menjawab kebutuhan, diperlukan metode dan media pembelajaran berbasis teknologi informasi dan komunikasi yang dapat menyajikan materi ajar secara mendalam, berwawasan luas, dan melatih peserta didik untuk menemukan pengetahuannya sendiri. Untuk merespon perkembangan teknologi dan informasi sekarang ini, diperlukan cara baru untuk menyampaikan materi ajar dalam sistem mandiri maupun terstruktur (Sagala, 2012: 64). Media pembelajaran yang dapat menutup kesenjangan diatas adalah multimedia interaktif pada materi pecahan siswa kelas 4 SD. Dengan adanya media ini nanti, penyampaian materi dilakukan secara tidak langsung, dapat dilakukan secara mandiri oleh peserta didik yang dikemas dengan beberapa pilihan menu awal berupa kompetensi, materi, ayo berlatih, soal evaluasi dan kesimpulan. Oleh karena itu peneliti mengembangkan multimedia interaktif yang dibutuhkan, untuk membawa peserta didik aktif dalam proses pembelajaran. Salah satu program yang dapat digunakan untuk membuat multimedia interaktif ini yaitu dengan menggunakan software Adobe Flash Creative Suite 6. Software tersebut memiliki fasilitas dan kemampuan dalam mendesain animasi secara mudah dan menyenangkan. Selain itu fasilitas yang tersedia adalah program Action Script.

Selanjutnya Model (PBL) mampu menyajikan pembelajaran yang dapat melatih peserta didik untuk aktif dan menemukan pengetahuannya sendiri. Model pembelajaran PBL yaitu sebagai lingkungan pembelajaran dengan berbasis pada masalah (Tan dalam Rusman, 2011: 229). Model PBL adalah pembelajaran berbasis masalah yang mengoptimalkan kemampuan berpikir siswa melalui proses kerja kelompok yang sistematis (Putra, 2013: 65). Sehingga untuk memberikan keaktifan dalam proses pembelajaran pada saat pengimplementasian multimedia interaktif model PBL disertakan. Langkah-langkah model PBL berlangsung dengan beberapa tahap menurut Dwi, dkk (2013: 11) yaitu: 1) Orientasi peserta didik pada masalah, 2) Mengorganisasikan peserta didik untuk belajar, 3) Membantu penyelidikan mandiri dan kelompok, 4) Mengembangkan dan menyajikan hasil karya, 5) Menganalisis dan mengevaluasi proses pemecahan masalah.

Multimedia interaktif untuk materi pecahan kelas 4 SD ini akan dikembangkan dengan model ASSURE. Model pengembangan ASSURE (Heinich, dkk dalam Arsyad, 2016: 67-69) mengatakan ada enam kegiatan utama dalam perencanaan pembelajaran sebagai berikut: 1) Menganalisis pembelajar (analyze leaner characteristic), 2) Menyatakan standar dan tujuan (State Objectives), 3) Memilih strategi, teknologi, media, dan materi (select, modify, or design materials). 4) Menggunakan teknologi, media dan material (utilize, media and material), 5) Mengharuskan partisipasi pembelajar (require learner participation), 6) Mengevaluasi proses belajar (Evaluate). Hasil penelitian dari Wahyudi, Indri dan Adi (2018: 68-81) yang mengembangkan model blended learning berbasis proyek, yang dikembangkan dengan model pengembangan ASSURE terbukti valid, praktis dan efektif.

\section{Metode}

Penelitian yang digunakan adalah jenis penelitian Research and Development $(R n D)$ atau pengembangan, yaitu suatu proses atau langkah-langkah untuk mengembangkan suatu produk baru atau dapat juga penyempurnaan produk yang sebelumnya sudah ada, yang dapat dipertanggungjawabkan Produk tersebut tidak selalu berbentuk perangkat keras (handware) atau benda seperti buku, modul, alat bantu pembelajaran di kelas, atau dapat berupa perangkat lunak (software) seperti program komputer untuk pengolahan data, pembelajaran dikelas, perpusatakaa ataupun model-model pendidikan, dll (Sukmadinata, 2015:164). Subjek dalam penelitian, yaitu: 1) Siswa kelas 4 SD N 01 Anggrasmanis, dengan jumlah 25 siswa, 2) Siswa kelas 4 SD N 01 Menjing, dengan jumlah 22 siswa, 3) Siswa kelas 4 SD N 01 Kadipiro, dengan jumlah 18 siswa, 4) Siswa kelas 4 SD N 01 Balong, dengan jumlah 25 siswa. Penelitian ini menggunakan langkah penelitian dan pengembangan yang dikemukakan Sukmadinata dan 
telah dimodifikasi oleh Mawardi (2014: 93). Terdiri dari 3 tahap yaitu studi pendahuluan, desain dan pengembangan produk, serta pengujian.

Penelitian ini akan dilaksanakan melalui 3 tahap, yaitu: 1) studi pendahuluan, 2) desain dan pengembangan produk, 3) pengujian. Langkah awal dalam penelitian ini adalah studi pendahuluan melalui observasi, wawancara dan studi dokumen. Langkah kedua yaitu desain dan pengembangan. Langkah ketiga yaitu pengujian produk yang dikembangkan yaitu uji pakar materi, uji pakar media dan uji coba terbatas. Penelitian ini menggunakan model pengembangan ASSURE, terdiri dari 6 tahapan yaitu 1) analyze learners, 2) state objectives, 3) select strategi, technology, media, and materials, 4) utilize media and materials, 5) require learner participation, 6) evaluated and revise (Smaldino, Lowther, \& Russell, 2012).

Selanjutnya analisis pada produk multimedia interaktif melalui uji pakar materi dan uji pakar media menggunakan teknik deskriptif persentase. Uji pakar adalah tahap untuk memvalidasi materi dan multimedia interaktif kepada pakarnya. Tujuan dari memvalidasi materi dan media adalah untuk mengetahui kelebihan dan kekurangan serta saran sebagai bahan perbaikan multimedia interaktif. Dalam memvalidasi materi dan media terdapat 10 indikator dari setiap 1 indikator terdapat skor 1-5. Masing-masing butir indikator yaitu skor (1 untuk yang sangat rendah, 2 untuk rendah, 3 untuk cukup, 4 untuk tinggi dan 5 untuk sanggat tinggi). Skor hasil pengukuran dengan menggunakan angket tertutup dari ahli media dijumlahkan dan ahli materi dijumlahkan, kemudian skor tersebut dipresentase dengan menggunakan rumus:

$$
\mathrm{AP}=\frac{\text { skor aktual }}{\text { skor ideal }} \times 100 \%
$$

\section{Keterangan :}

AP : Angka Persentase

Skor Aktual : Skor yang diberikan oleh validator ahli.

Skor Ideal : Skor maksimal hasil kali antara jumlah item dengan skor maksimal masingmasing item.

Tabel 1. Rentang skor validasi materi dan multimedia interaktif

\begin{tabular}{cc}
\hline Skor & Kriteria \\
\hline $81-100 \%$ & Sangat Tinggi \\
$61-80 \%$ & Tinggi \\
$41-60 \%$ & Cukup \\
$21-40 \%$ & Rendah \\
$1-20 \%$ & Sangat rendah \\
\hline
\end{tabular}

Berdasarkan tabel di atas hasil validasi media dari multimedia interaktif dapat dikatakan layak digunakan apabila angka rata-rata persentase mencapai minimal $\geq 61 \%$ (Mawardi, 2014:113).

Hasil penilaian pakar materi dan media akan disajikan dalam tabel 2 berikut:

Tabel 2 Hasil Validasi Materi dan Media

\begin{tabular}{lccc}
\hline \multirow{2}{*}{ No } & Validasi & $\begin{array}{c}\text { Persen- } \\
\text { tase }\end{array}$ & Kategori \\
\hline 1 & Materi & $86 \%$ & Sangat Tinggi \\
2 & Media & $88 \%$ & Sangat Tinggi \\
\hline
\end{tabular}

Berdasarkan hasil validasi materi dan media yang dikembangkan dalam kategori sangat tinggi (nilai persentase $\geq 61 \%$ ) sehingga multimedia interaktif sudah layak untuk digunakan.

Tahap analisis data pada uji coba terbatas menggunakan teknik deskriptif kuantitatif, kualitatif dan uji beda. Teknik uji beda rata-rata hasil belajar matematika siswa dilakukan dengan menggunakan teknik parametik uji independent sample $T$-test yaitu dengan membandingkan hasil pretest dan posttest. Sebelum melakukan uji T-test data akan di uji 
normalitas dan uji homogenitas terlebih dahulu sebagai persyaratan sebelum uji T-test dilakukan.

Selain itu dilakukan teknik uji non tes melalui angket dan observasi. Angket digunakan untuk mengetahui respon guru dan siswa terhadap implementasi multimedia interaktif dalam pembelajaran. Angket respon guru terdiri dari 8 butir indikator dan angket respon siswa terdiri dari 5 butir indikator. Observasi dilakukan guna mengamati bagaimana guru dan siswa melakukan pembelajaran menggunakan produk multimedia interaktif, terdapat 25 butir indikator. Kategori untuk masing-masing indikator yaitu "IYA" dan "TIDAK".

\section{Hasil Dan Pembahasan}

Berdasarkan studi pendahuluan tentang kesenjangan yang ditemui di sekolah, penelitian ini menghasilkan produk berupa multimedia interaktif materi pecahan untuk siswa kelas 4 SD. Hasil pengembangan produk model ASSURE yang terdiri dari 6 tahapan pengembangan 1) analyze learners, 2) state objectives, 3) select strategi, technology, media, and materials, 4) utilize media and materials, 5) require learner participation, 6) evaluated and revise (Smaldino, Lowther, \& Russell, 2012). Setiap tahapan pengembangan produk multimedia interaktif dapat dijelaskan sebagai berikut:

\section{Tahap Analyze learners Characteristic}

Langkah pertama yang dilakukan yaitu mengidentifikasi karakteristik peserta didik yaitu dengan observasi dan wawancara dengan guru di SD N 01 Anggrasmanis. Hasil pengamatan di SD N 01 Anggrasmanis diperoleh bahwa, guru kurang memanfaatkan media pembelajaran berbasis teknologi informasi dan komunikasi pada saat pembelajaran. Hal serupa juga terjadi di SD N 1 Kembangkuning, bahwa guru belum memanfaatkan IPTEK dalam membuat media pembelajaran (Sundari, 2018). Siswa belum aktif dalam mengikuti kegiatan pembelajaran dan cenderung pasif sehingga perhatian siswa belum sepenuhnya fokus pada pembelajaran, yang berdampak pada hasil belajar matematika siswa kelas 4 SD N 01 Anggrasmanis rendah. Dari 25 siswa terdapat 7 siswa yang lulus KKM dengan persentase $28 \%$. Ada 18 siswa yang belum lulus KKM dengan persentase $72 \%$. Data ini dijadikan sebagai data awal untuk pengembangan multimedia interaktif sehingga dapat ditentukan metode dan proses pembelajaran yang efektif dan efisien.

\section{Tahap State Objectives}

Langkah kedua adalah menetapkan tujuan pembelajaran yang didasarkan pada hasil analisis peserta didik. Berdasarkan hasil analisis dan standar kompetensi, kompetensi dasar, indikator serta materi pembelajaran yang tercantum pada kurikulum yang didasarkan pada prinsip multimedia interaktif.

Standar Kompetensi (SK) dalam penelitian ini adalah 6. Menggunakan pecahan dalam pemecahan masalah. Kompetensi Dasar (KD) yang dipilih adalah 6.1 menjelaskan arti pecahan dan urutannya. Selanjutnya indikator yang dipilih adalah 6.1.1 Mendefinisikan arti bilangan pecahan, 6.1.2 Mendefinisikan pengertian pembilang dalam pecahan, 6.1.3 Mendefinisikan pengertian penyebut dalam pecahan, 6.1.4 Mengurutkan bilangan pecahan biasa berpenyebut sama dari terkecil sampai terbesar, 6.1.5 Mengurutkan bilangan pecahan biasa berpenyebut sama dari terbesar sampai terkecil, 6.1.5 Mengurutkan bilangan pecahan biasa berpenyebut berbeda dari terkecil sampai terbesar, 6.1.6 Mengurutkan bilangan pecahan biasa berpenyebut berbeda dari terbesar sampai terkecil, 6.2.1 Menyederhanakan pecahan biasa, 6.3.1 Menjumlahkan pecahan biasa berpenyebut sama, 6.3.2 Menjumlahkan pecahan biasa berpenyebut berbeda, 6.4.1 Mengurangkan pecahan biasa berpenyebut sama, 6.4.2 Mengurangkan pecahan biasa berpenyebut berbeda. Pemetaan SK, KD dan indikator menjadi dasar dalam membuat RPP dan merancang materi.

\section{Tahap Select Modify or Design Method, Media Or Materials}

Langkah ketiga yaitu menentukan metode, model dan media yang nantinya digunakan untuk pembelajaran tatap muka dengan guru, maupun belajar secara mandiri karena ketiga komponen tersebut dapat membantu peserta didik dalam mencapai tujuan pembelajaran serta 
prinsip multimedia interaktif materi pecahan dapat meningkatkan hasil belajar matematika di kelas 4 SD.

Langkah awal pembuatan multimedia interaktif pada materi pecahan yaitu: 1) Membuka aplikasi adobe flash CS 6, 2) Membuat dan memilih warna bacground, 3) Membuat karakter, 4) Membuat petunjukdalam menggunakan multimedia interaktif, 5) Memasukkan materi dalam multimedia interaktif, 6) Membuat tulisan atau font dari masing-masing halaman, 7) Membuat tombol atau menu yang akan digunakan dalam multimedia interaktif, 8) Merekam suara untuk dijadikan narasi dalam multimedia interaktif, 9) Memasukkan narasi sesuai dengan tulisan pada setiap halaman, 10) Memasukkan soal pada multimedia interaktif, 11) Menentukan skor pada setiap jawaban yang salah dan jawaban yang benar, 12) Melakukan desain dan coding pada setiap tombol supaya berfungsi dengan baik.

Tahap Utilize Media and Materials

Langkah keempat adalah memanfaatkan media dan material pembelajaran yang sudah dipilih. Sebelum diterapkan di sekolah, komponen tersebut perlu dilakukan penilaian/validasi pakar (pakar materi dan media pembelajaran) untuk melihat kualitas dan kelayakan multimedia interaktif yang dibuat. Adapun tahapan pembuatan multimedia interaktif pada materi pecahan dan hasil uji dari pakar materi dan media dapat diuraikan sebagai berikut:

1) Halaman Awal

Halaman awal merupakan tampilan awal berisi judul multimedia interaktif, nama peneliti, dan nama dosen pembimbing, dapat dilihat pada gambar 1 di bawah ini:

2) Halaman Petunjuk

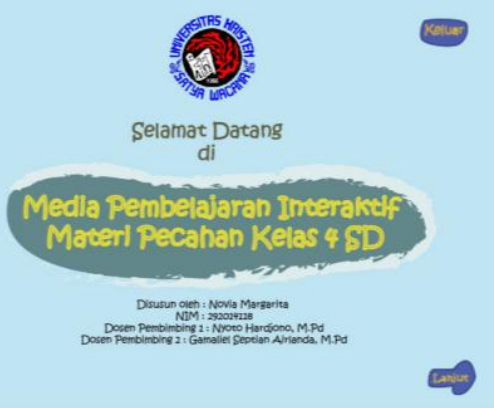

Gambar 1. Tampilan Menu Awal

Halaman petunjuk berisi tentang keteranga dari penggunaan setiap tombol yang terdapat pada multimedia interaktif. Halaman petunjuk dapat dilihat pada gambar 2 berikut:

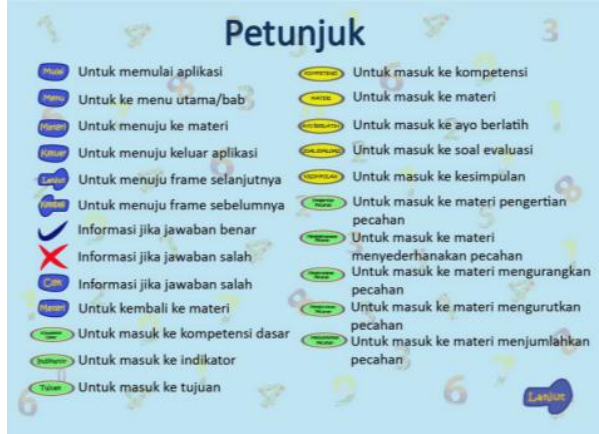

3) Halaman Menu Utama

Gambar 2. Tampilan Petunjuk

Halaman menu berisi menu tentang kompetensi, materi, ayo berlatih, soal evaluasi dan kesimpulan. Setiap menutersebut memiliki fungsi yang berbeda-beda, misalkan apabila ingin melihat materi, kita dapat mengklik menu materi yang ada pada halaman utama. Tampilan menu dapat dilihat pada gambar 3 berikut: 
4) Menu Kompetensi

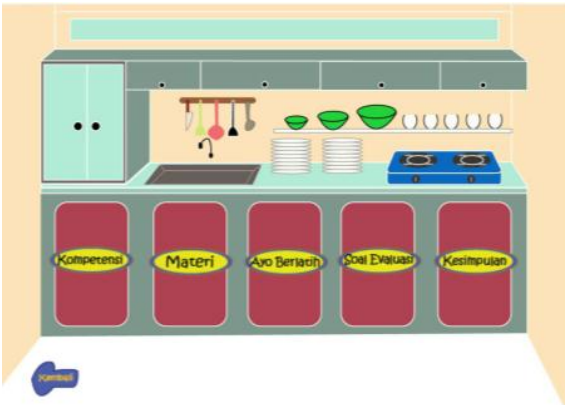

Gambar 3 Menu Utama

Pada menu kompetensi berisi KD, Indikator dan tujuan pembelajaran yang ada dalam multimedia interaktif pada materi pecahan. Tampilan menu kompetensi dapat dilihat pada gambar 4 berikut:

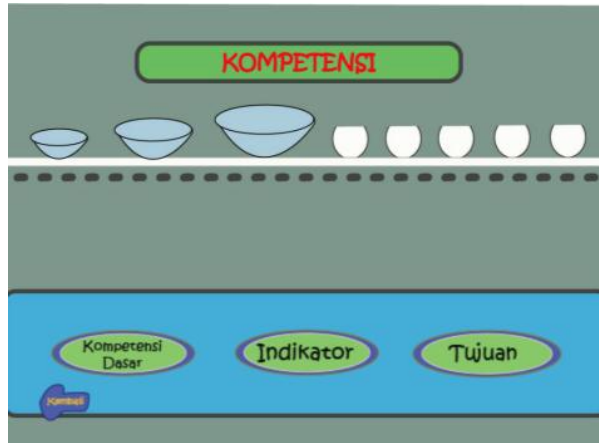

Gambar 4 Menu Kompetensi

Menu Kompetensi Dasar dapat dilihat pada gambar 5 berikut :

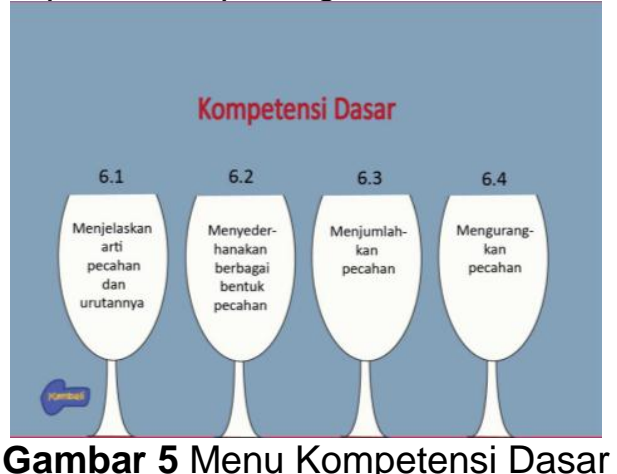

Menu Indikator dapat dilihat pada gambar 6 berikut :

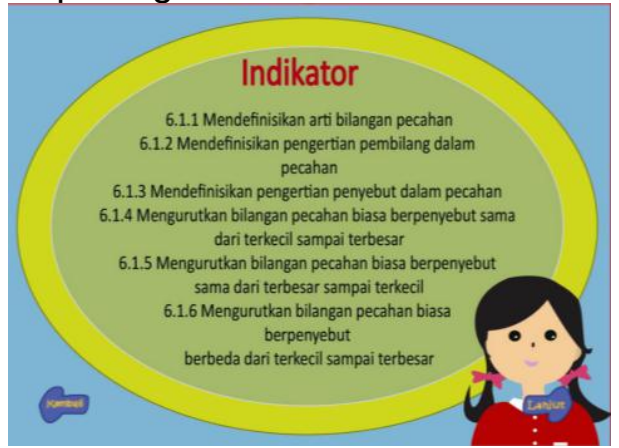

Gambar 6 Menu Indikator

Selanjutnya menu tujuan pada multimedia ini dapat dilihat pada gambar 7 berikut : 


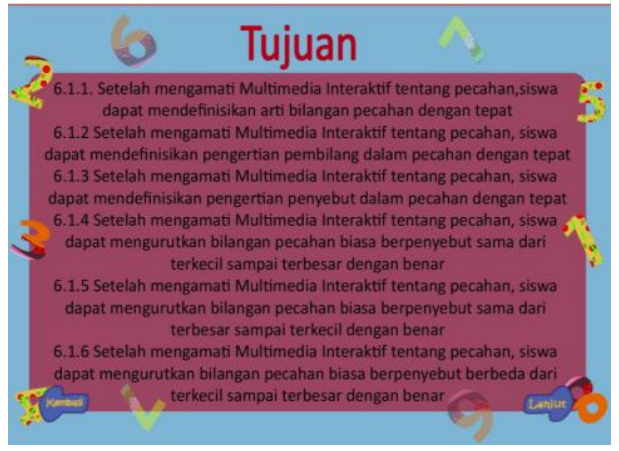

5) Menu Materi

Gambar 7 Menu Tujuan

Pada menu materi berisikan tentang materi pengertian pecahan, mengurutkan pecahan, menyederhanakan pecahan, menjumlahkan pecahan, mengurangkan pecahan. Tampilan menu materi dapat dilihat pada gambar 8 berikut :

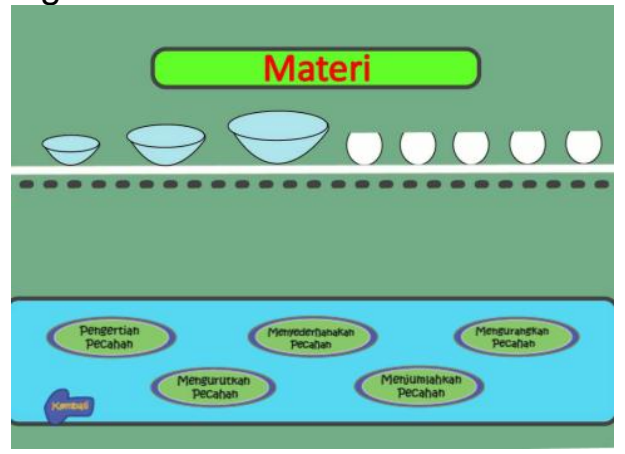

Gambar 8 Menu Materi

Tampilan menu Pengertian Pecahan dapat dilihat pada gambar 9 berikut :

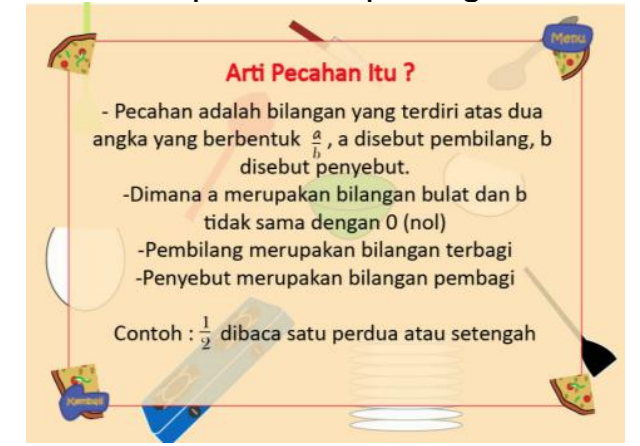

Gambar 9 Menu Pengertian Pecahan

Tampilan Menu Mengurutkan Pecahan dapat dilihat pada gambar 10 berikut :

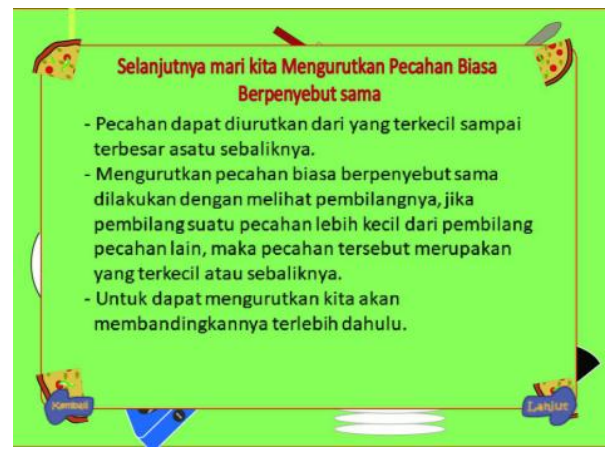

Gambar 10 Menu Mengurutkan Pecahan 
Tampilan Menu Menyederhanakan Pecahan dapat dilihat pada gambar 11 berkut :

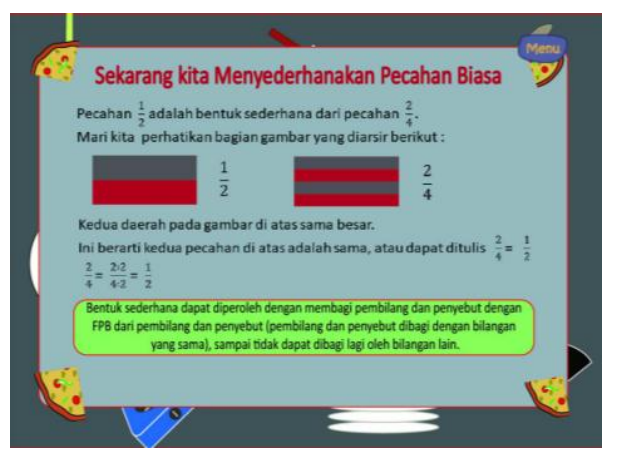

Gambar 11 Menu Menyederhanakan Pecahan

Tampilan Menu Menjumlahkan Pecahan dapat ddilihat pada gambar 12 berikut :

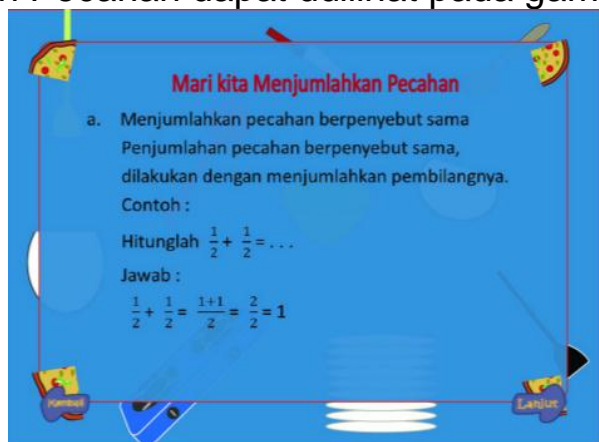

Gambar 12 Menu Menjumlahkan Pecahan

Tampilan Menu Mengurangkan Pecahan dapat ddilihat pada gambar 13 berikut :

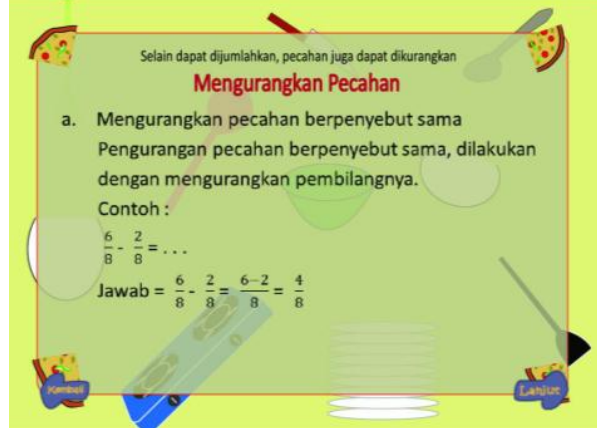

Gambar 13 Menu Mengurangkan Pecahan

6) Menu Ayo Berlatih

Menu ayo berlatih ini berisi 5 level yang didalamnya berisi soal untuk latihan. Siswa dapat memilih level yang diinginkan dan pada setiap level siswa dapat menuliskan jawaban pada setiap kotak kosong yang sudah disediakan. Tampilan menu ayo berlatih dapat dilihat pasa gambar 14 berikut:

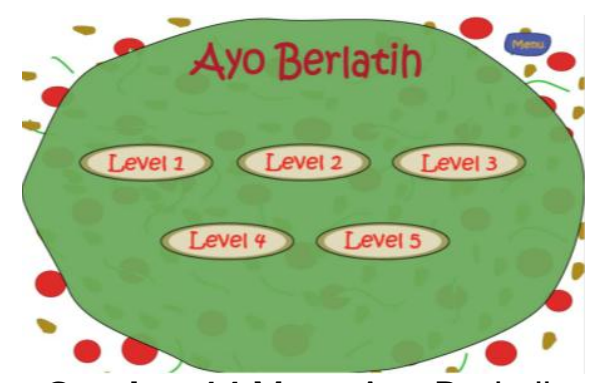

Gambar 14 Menu Ayo Berlatih 
Contoh tampilan pada level dapat dilihat pada gambar 15 berikut :

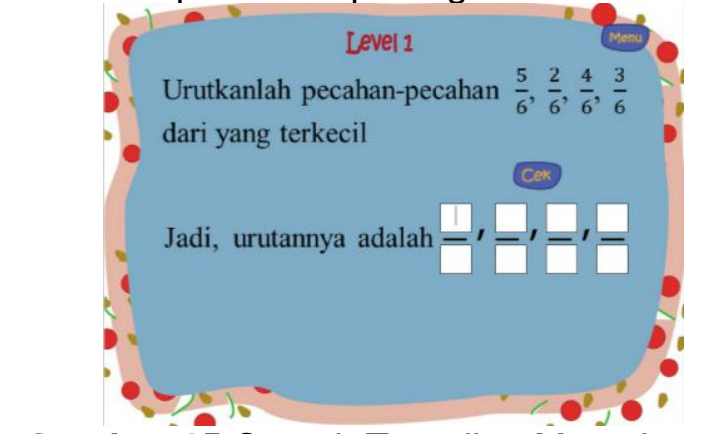

Gambar 15 Contoh Tampilan Menu Level 1

7) Menu Soal Evaluasi

Pada menu soal evaluasi berisi 5 soal yang harus dijawab setiap soal memiliki nilai 20 apabila dijawab dengan benar dan apabila salah nilai 0 . Nilai akan muncul diakhir setelah semua soal di jawab. Berikut tampilan petunjuk mengerjakan soal dan tampilan nilai dapat dilihat pada gambar 16 berikut:

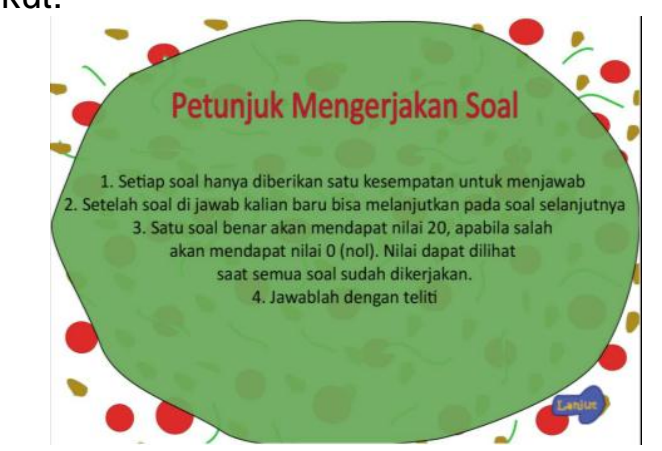

Gambar 16 Petunjuk Mengerjakan Soal

Tampilan menu soal pada menu soal evaluasi dapat dilihat pada gambar 17 berikut :

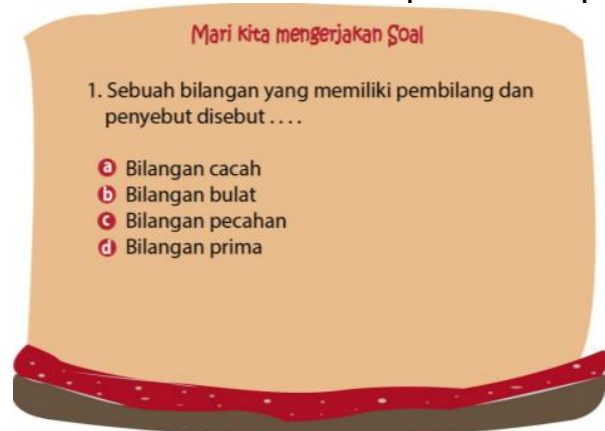

Gambar 17 Soal Evaluasi

Apabila soal dijawab dengan benar maka akan muncul tanda centang pada samping jawaban, dapat dilihat pada gambar 18 berikut : 


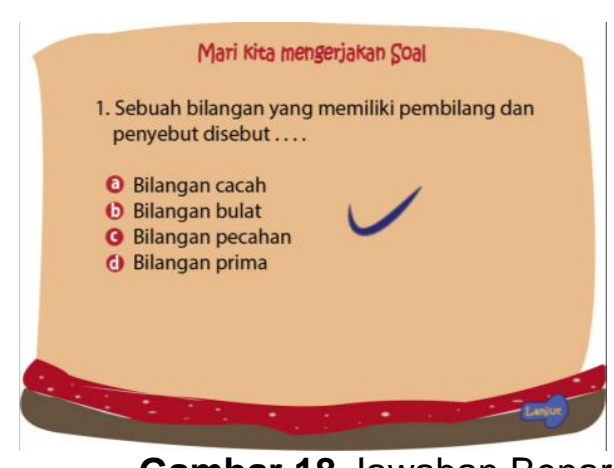

Gambar 18 Jawaban Benar

Setelah menjawab semua soal, secara otomatis akan keluar nilai. Dapat dilihat pada gambar 19 berikut :

8) Menu Kesimpulan

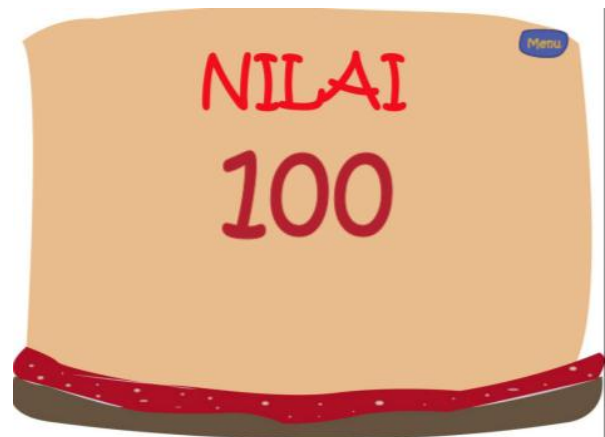

Gambar 19 Menu Nilai

Pada tampilan menu kesimpulan berisi tentang kesimpulan dari materi yang sudah dipelajari dalam multimedia interaktif. Halaman kesimpulan dapat dilihat pada gambar 20 berikut:

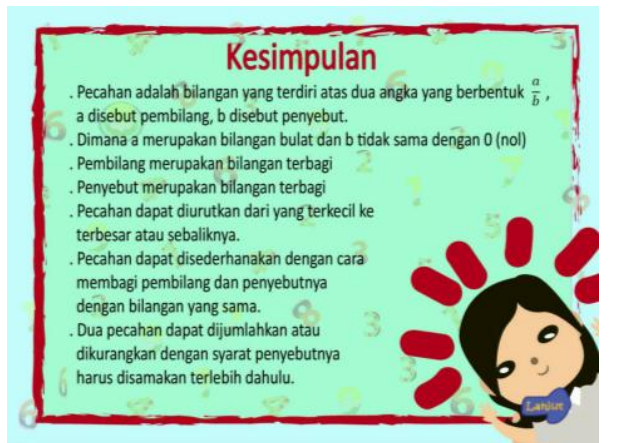

Gambar 20 Menu Kesimpulan

\section{Tahap Require Learners Participation}

Tahap selanjutnya adalah melibatkan peserta didik dalam proses pembelajaran. Peserta didik yang dilibatkan untuk penggunaan multimedia interaktif dalam Uji coba terbatas yaitu dilakukan di dua Sekolah Dasar yaitu SD N 01 Anggrasmanis dan SD N 01 Menjing. Sedangkan untuk mengetahui perbedaan antara sekolah yang menggunakan media dan sekolah yang tidak menggunakan media maka peneliti menggunakan dua sekolah dasar yang tidak menggunakan media yaitu SD N 01 Balong dan SD N 01 Kadipiro.

Berdasarkan hasil uji normalitas menggunakan shapiro-wilk pada 2 sekolah yang tidak menggunakan media didapatkan hasil pretest dengan sig. 0,192 dan hasil posttest didapatkan sig. 0,103. Karena nilai signifikansi hasil pretest dan posttest $>0,05$ maka data berdistribusi normal. Selanjutnya hasil uji normalitas shapiro-wilk pada 2 sekolah yang menggunakan media didapatkan hasil pretest dengan sig. 0,089 dan hasil posttest didapatkan sig. 0,053 hal ini berarti data berdistribusi normal karena nilai signifikansi hasil pretest dan posttest $>0,05$. 
Setelah uji normalitas data akan diuji homogenitas sebagai syarat dalam uji T-test, karena harus berdistribusi homogen terlebih dahulu. Hasil Test of Homogeneity of Variances pada dua SD yang tidak menggunakan media didapatkan nilai sig. 0,241. Sedangkan hasil Test of Homogeneity of Variances pada dua SD yang menggunakan media didapatkan nilai sig. 0,754 .

Berdasarkan uji Independent sample T-Test pada dua SD yang tidak menggunakan media didapatkan rata-rata pretest adalah 72,56 dan posttest adalah 80,12 dengan nilai sig.(2tailed) 0,004. Selanjutnya uji Independent sample T-Test pada dua SD yang menggunakan media didapatkan rata-rata pretest adalah 75,74 dan posttest adalah 83,62 dengan nilai sig.(2tailed) 0,000 . Artinya ada perbedaan antara sekolah yang tidak menggunakan media dan yang menggunakan media.

Analisis data dari 2 sekolah yang tidak menggunakan media dan 2 sekolah yang menggunakan media diketahui bahwa multimedia interaktif efektif digunakan untuk proses pembelajaran, karena adanya peningkatan rata-rata nilai hasil belajar matematika dari sekolah yang menggunakan media. Hasil belajar matematika peserta didik dengan tidak menggunakan media dan menggunakan media hasilnya lebih baik dibandingkan dengan yang tidak menggunakan media.

\section{Tahap Evaluate and Revise}

Tahap terakhir berdasarkan hasil penilaian ahli dan implementasi pembelajaran terdapat beberapa hal yang harus diperbaiki. Hasil yang diperoleh dari validasi pakar materi sebesar $86 \%$ dengan kategori sangat tinggi. Selanjutnya hasil validasi media sebesar $88 \%$ dengan kategori sangat tinggi. Berdasarkan persentase hasil rata-rata pengembangan multimedia interaktif sebagai media pembelajaran dikatakan layak, karena angka persentase dari validasi materi dan media $>61 \%$.

Pada bagian materi sesuai saran validator perlu ditambahkan materi mengurutkan pecahan biasa berpenyebut sama, sehingga penulis menambahkan tentang materi tersebut. Selanjutnya tentang multimedia interaktif sesuai saran validator, ukuran font dan tingkat keterbacaan teks susah dibaca oleh anak sehingga perlu diganti dengan font yang mudah dibaca oleh anak. Selain itu dalam satu halaman jangan terlalu penuh tulisan dan perlu adanya penambahan halaman. Serta volume narasi yang ada pada multimedia interaktif kurang keras sehingga perlu dinaikkan volumenya.

Angket respon guru dari ke 2 SD yang diteliti menggunakan multimedia interaktif diperoleh "IYA" dari indikator 1 sampai 8. Angket respon siswa dari 2 SD yang menggunakan media didapatkan rata-rata siswa menjawab "IYA" dari indikator 1 sampai 5 . Saran dan kesan dari guru kelas tentang pendapat multimedia interaktif yaitu multimedia interaktif sudah sesuai dengan materi kelas 4 SD. Materi di dalam multimedia interaktif dikemas dengan baik dan menarik.

Selanjutnya untuk lembar observasi rata-rata diperoleh isian "IYA" dari 1 sampai 25 indikator. Pendapat dari observer tentang multimedia interaktif yaitu penggunaan multimedia dalam pembelajaran sangat membantu penyampaian materi pada siswa. Siswa sangat antusias dan termotivasi dalam penggunaan multimedia ini, aktifitas siswa lebih banyak dan tidak membosankan dalam proses pembelajaran. Soal evaluasi yang bisa mengetahui nilainya membuat siswa semangat untuk mengerjakannya.

\section{Simpulan dan Saran}

Berdasarkan hasil penelitian dan pembahasan yang telah dilakukan, maka dapat diambil simpulan bahwa multimedia interaktif yang dikembangkan valid dan materi yang terdapat dalam multimedia interaktif dapat membawa anak untuk belajar secara tidak langsung dan dapat belajar secara mandiri. Ditinjau dari aspek validasi pakar materi dengan skor persentase $86 \%$ dengan kriteria yang menunjukkan kategori sangat tinggi. Validasi media dengan skor persentase $88 \%$ dengan kategori sangat baik. Hal ini ditunjukkan pada 2 SD yang tidak 
menggunakan media dihasilkan rata-rata nilai pretest 72,56 dan posttest 80,12 serta sig.(2tailed) 0,004 . Selanjutnya pada 2 SD yang menggunakan media dihasilkan rata-rata pretest 75,74 dan posttest 83,62 dan sig.(2-tailed) 0,000.

Berdasatrkan hasil penelitian ini, maka disarankan untuk pengembangan multimedia interaktif sebagai media berbasis komputer dapat digunakan untuk materi lainnya. Sehingga multimedia yang dikembangkan nantinya dapat mempermudah siswa dalam memahami materi dan menambah motivasi belajar matematika. Memberikan kesempatan untuk belajar secara tidak langsung dan mandiri bagi siswa dapat mengembangkan kreativitasnya.

\section{Daftar Rujukan}

Arsyad, Azhar. 2016. Media Pembelajaran. Jakarta: PT. Raja Grafindo Persada

Giarti, Sri. 2014. Peningkatan Keterampilan Proses Pemecahan Masalah dan Hasil Belajar Matematika Menggunakan Model PBL Terintegrasi Penilaian Autentik pada Siswa Kelas VI SDN 2 Bengle Wonosegoro. Scholaria. 4 (3), 13-27.

Hajar, Nasaul Azmy, A.Y Djoko Darmono, A,B,C. (2015). Pengaruh Model pembelajaran Problem Based Learning(pbl) Untuk Meningkatkan Hasil Belajar Siswa x-3 Pada Mata Pelajaran Sosiologi sma Negreri Kebakkramat Tahun Pelajaran 2015-2016 Jurnal Ilmiah Pend.Sos Ant, 7 (2).

Henny Dewi Koeswati dkk. (2018). Model Problem Based Learning (PBL) Berbasis Media Interaktif Untuk Meningkatkan Keterampilan Berpikir Kritis dan Hasil Belajar Pada Sub Tema Lingkungan Tempat Tinggalku Kelas 4 SD. Temanggung: UKSW.

Mawardi. (2014). Model Desain Pembelajaran Konsep Dasar PKn Bebrbasis Belajar Mandiri Menggunakan Modle. Salatiga: Widya Sari Press.

Pasaribu, R. (2015). Penerapan Model Problem Based Learning" untuk Meningkatkan Aktivitas dan Hasil Belajar Peserta didik Kelas XI SMA Negeri 1 Semarang Tahun Pelajaran 2015/2016. Semarang: UNNES.

Permendiknas No 16 Tahun 2007 Tentang Standar Kualifikasi Akademik dan Kompetensi Guru

Permendikbud Nomor 81 A Tahun 2013 Tentang Implementasi Kurikulum.

Putra, Stitava Rizema. 2013. Desain Belajar Mengajar Kreatif Berbasis Sains. Jogyakarta: Diva Press

Rusman. 2011. Model-Model Pembelajaran. Jakarta: PT. Raja Grafindo Persada.

Smaldino, S. E., Lowther, D. L., \& Russell, J. D. 2012. Instructional Technology and Media for Learning. New Jersey: Pearson Merril Prentice Hall Inc.

Septiana, Y. (2012). Pendekatan Problem Based Learning (PBL) Untuk Meningkatkan Pemahaman Konsep Peserta didik Kelas IV SD Negeri Cigugur Girang Kecamatan Parongpong Kabupaten Bandung Barat.

Sukmadinata, Nana Syaodih. 2015. Metode Penelitian Pendidikan. Bandung: Remaja Rosdakarya Offset. 
Sundari, Lilis Retno., Suroso., Yustinus. 2018. Pengembangan Multimedia Interaktif Menggunakan Adobe Flash CS 3 Profesional untuk Meningkatkan Hasil Belajar IPS Siswa Kelas 4 SD. Jurnal Pendidikan Berkarakter. 1 (1), 271-279.

Suriatmaja, Dwi, dkk. 2013. Pengembangan Multimedia Interaktif Mata Pelajaran TIK Pada Siswa Kelas VIII Semester Ganjil SMP Nengeri 3 Sawan Tahun 2012/2013. Jurnal Edutech Undiksha. Vol 1. No 2

Syaiful, Sagala. 2012. Supervisi Pembelajaran. Bandung: Alfabeta.

Giarti, Sri. 2014. Peningkatan Keterampilan Proses Pemecahan Masalah dan Hasil Belajar Matematika Menggunakan Model PBL Terintegrasi Penilaian Autentik pada Siswa Kelas VI SDN 2 Bengle Wonosegoro. Scholaria. 4 (3), 13-27.

Hajar, Nasaul Azmy, A.Y Djoko Darmono, A,B,C. (2015). Pengaruh Model pembelajaran Problem Based Learning(pbl) Untuk Meningkatkan Hasil Belajar Siswa x-3 Pada Mata Pelajaran Sosiologi sma Negreri Kebakkramat Tahun Pelajaran 2015-2016 Jurnal Ilmiah Pend.Sos Ant, 7 (2)

Henny Dewi Koeswati dkk. (2018). Model Problem Based Learning (PBL) Berbasis Media Interaktif Untuk Meningkatkan Keterampilan Berpikir Kritis dan Hasil Belajar Pada Sub Tema Lingkungan Tempat Tinggalku Kelas 4 SD. Temanggung: UKSW.

Komalasari, K. (2010). Pembelajaran Kontekstual Konsep dan Aplikasi. Bandung: PT Refika Aditama.

Pasaribu, R. (2015). Penerapan Model Problem Based Learning" untuk Meningkatkan Aktivitas dan Hasil Belajar Peserta didik Kelas XI SMA Negeri 1 Semarang Tahun Pelajaran 2015/2016. Semarang: UNNES.

Purwanto. (2010). Evaluasi Hasil Belajar. Yogyakarta: Pustaka Belajar.

Rusman. (2017). Belajar \& Pembelajaran "Berorientasi Standar Proses Pendidikan". Jakarta: Kencana.

Sagala, Syaiful., 2010. supervisi Pembelajaran Dalam Profesi Pendidikan Bandung: Alfabeta. Hal 258

Septiana, Y. (2012). Pendekatan Problem Based Learning (PBL) Untuk Meningkatkan Pemahaman Konsep Peserta didik Kelas IV SD Negeri Cigugur Girang Kecamatan Parongpong Kabupaten Bandung Barat.

Sudjana, Nana. (2010). Dasar-dasar Proses Belajar Mengajar. Bandung: Sinar Baru Algesindo.

Suryani, D. (2016). Penerapan Problem Based learning untuk Meningkatkan Pemahaman Hasil Belajar Peserta didik Kels IV SDN Leuwiliang Sumedang pada Subtema Kebersamaan dalam Keberagaman. Sumedang: Unpas.

Wahyudi., Anugraheni, I., \& Adi, w. 2018. Pengembangan Model Blended Learning Berbasis Proyek untuk Menunjang Kreatifitas Mahasiswa Merancang Pembelajaran Matematika Sekolah Dasar. Jurnal Ilmiah Pendidikan Matematika. Vol 6(2). 68-81 
Journal for Lesson and Learning Studies Vol. 1 No. 3, 2018

P-ISSN : 2615-6148, E-ISSN : 2615-7330

Wahyudi, dan Kriswandani. 2013. Pengembangan Pembelajaran Matematika SD. Salatiga: Widya Sari Press 